Article

\title{
The Strength of CEOs'Influence on CSR in Chinese listed Companies. New Insights from an Agency Theory Perspective
}

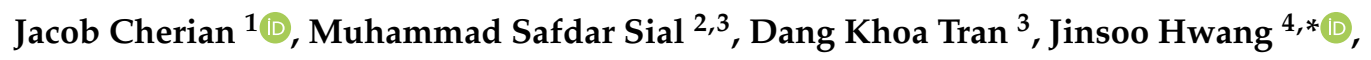 \\ Thai Hong Thuy Khanh ${ }^{5, *}$ and Mansoor Ahmed ${ }^{6}$ \\ 1 College of Business, Abu Dhabi University, P.O Box 59911 Abu Dhabi, UAE; jacob.cherian@adu.ac.ae \\ 2 Department of Management Sciences, COMSATS University Islamabad (CUI), Islamabad 44000, Pakistan; \\ safdar.sial786@gmail.com \\ 3 Institute of Business Research, University of Economics, Ho Chi Minh City, Ho Chi Minh City 700000, \\ Vietnam; khoatd@ueh.edu.vn \\ 4 The College of Hospitality and Tourism Management, Sejong University, 98 Gunja-Dong, Gwanjin-Gu, \\ Seoul 143-747, Korea \\ 5 Faculty of Finance and Accounting, Nguyen Tat Thanh University, Ho Chi Minh City 700000, Vietnam \\ 6 Department of Management and Business Administration, G.d'Annunzio University, 65127 Pescara, Italy; \\ mansoor.ahmed@unich.it \\ * Correspondence: jhwang@sejong.ac.kr (J.H.); thtkhanh@ntt.edu.vn (T.H.T.K.)
}

Received: 19 February 2020; Accepted: 10 March 2020; Published: 12 March 2020

\begin{abstract}
This study examined the strength of CEOs' influence on CSR in Chinese listed companies. The companies chosen belonged to the non-financial sector and were listed in the Shanghai stock exchange from 2010 to 2019. The data was extracted from audited annual reports of companies including the director's report, chairman's statements, and notes to financial statements. We applied OLS regression as a baseline methodology to determine the extent and impact of CEO power on CSR disclosures. The results indicated significantly negative relationship between the CEOs' power and CSR disclosure. Our results showed that separate roles of chairman and CEO can reduce agency problems and increase the CSR disclosures. This study is of importance for regulators, as it enforces the view that regulators and policymakers should continue efforts to improve corporate governance practices and CSR reporting in China, as these changes will not only improve the performance of companies but also befit society at large.
\end{abstract}

Keywords: CEO power; corporate social responsibility disclosure; agency theory; China

\section{Introduction}

One of the major debates that have recently gained attention relates to the roles of CEO and chairman of the board of directors (CEO duality). It has been argued that these two positions should be held by separate personnel. Proponents of these arguments point to the fact that the performance of the company partially depends upon the performance of the directors and CEO as they hold most of the power in the hierarchy [1]. These people are charged with the responsibility of determining the direction of the company by implementing the policies deemed favorable for the growth and wellbeing of the company. According to this school of thought, the power should not be concentrated with one person and if the posts of chairman and CEO are separated, they act as a counterbalance for each other [2-4]. The research also indicates that these individuals also have a strong influence on the reporting pattern of the company. The power-sharing or power concentration in corporate structure has a great impact on the corporate governance of companies. 
Due to an increase in shareholder activism, legal requirements, and awareness amongst the general public, this topic is attracting ever-increasing attention from a research point of view. As a result of these issues, CSR disclosure has also gained much-needed attention [5,6].One of the major issues seems to be that the researchers have concentrated their efforts based upon the agency theory, by focusing particularly on relationship between CSR reporting and characteristics of boards of directors (hereafter BoDs), such as the number of non-executive directors, the perks and privileges of directors, etc. $[7,8]$. This research has shed light on the underlying problem but while conducting such research, one has to keep in mind that CSR disclosure cannot be compared to other disclosures, such as financial disclosures because it is voluntary and firms do not follow a strict standard in most countries. Thus, agency theory is very useful.

This study examines the strength of CEOs' influence on CSR in Chinese listed companies. China is an ideal country for such research as it is an emerging country and in the last few decades emerged as a major economic power. As the Chinese economy is rapidly growing, it is also evolving at a similar pace. In addition, Chinese companies are quickly adapting to best practices of reporting, such as CSR reporting [9]. This can mainly be attributed to high-profile environmental concerns and disasters perpetrated by Chinese companies. These disasters have been highlighted around the world because they not only caused environmental damage but also claimed the lives of hundreds of people in mining and other industries. These events led to in-depth examinations of CSR reports published by Chinese companies [10].These incidents are the results of activism from stakeholders, which are related to labor rights, working conditions, employee health, and safety regulations. This, to some extent, has forced Chinese companies to observe better labor and CSR practices. In addition, most of the companies in which the CEO holds considerable powers are state-owned and operated enterprises, thus demonstrating the dual role of CEO [11]. Many Chinese companies have adopted the Anglo-American model of corporate governance, which is based upon a power-sharing structure, not only helping to provide necessary checks and balances in terms of power structure but also favoring the inclusion of non-executive directors inboards of governance. However, this is only applicable to large scale organizations that might face shareholder activism; small- and medium-sized enterprises are mainly family-owned and thus they exhibit the CEO duality [12,13].

The present study contributes to the existing literature by investigating the impact of the power structure on corporate social disclosure in an Asian corporate setting. We explored the impact of the power structure on such voluntary disclosure by utilizing the institutional and economic settings of China. As China is becoming a global economic power, its attitudes and corporate culture are also changing $[14,15]$. These changes are also reflected in the legal reforms carried out by the Chinese government over time. Our study also included the perspective of family-owned and operated businesses in regard to voluntary corporate social reporting.

The results of our study showed that CEO power had a great impact on the CSR disclosure provided by Chinese companies. The major finding can be summarized as firstly, in order to improve the CSR disclosure, a comprehensive understanding of CSR needs to propagate, as only then will the policymakers consider it important. There seemed to be a lack of in-depth knowledge regarding CSR. Policy makers did not consider its positive impacts on the company, in line with findings of [16], who holds that due to these sorts of reasons, many governments have made CSR reporting compulsory rather leaving it as optional or part of codes of best practices. Secondly, we found that users of the CSR reports had to study the reports in perspective of the company issuing the report, as the information disclosed under voluntary disclosure regimes mostly lacked standardized formats. Lastly, this study endorsed the finding of [17], who has researched a similar topic in voluntary disclosure regimes.

The next section, Section 2, of this paper includes the theoretical framework, literature review, and research hypothesis. Section 3 is utilized to develop a research hypothesis followed by "research design" which explains the methodology. Section 4 part discusses the results. Finally, Section 5 comprises the major finding along with their implications, titled "Conclusion". 


\section{Theoretical Framework, Literature Review, and Research Hypothesis}

\subsection{Theoretical Framework (Agency Theory Perspective)}

The conflict between the principals (shareholders) and the agents (managers) is deemed to be inevitable. This might create unique characteristics in emerging markets and widely cited in many studies [18-25]. Jensen and Meckling [26] connect it to the actions of management as they veer off course when they make decisions that benefit them more than the shareholders; in other words, they intend to maximize their personal benefits at the cost of shareholders' wealth. Since the main objective of any commercial enterprise is to maximize shareholders' wealth, these actions tend to contradict the main objective of the enterprise. This also causes asymmetry in the disclosure of information as management is pursuing their self-interest instead of shareholders' interest. Management is reluctant to disclose information that might highlight their perusal of self-interest [27]. The agency problems connects in situations where the agents have very little or no financial interest in the company since they are also the key decision-makers [28]. According to Boyd [29], the board of directors exists in order to align the interests of shareholders and management, if one follows the agency theory.

Nada, Kholief [30] state that in order for the BoD to fulfill its main objective stated above, the positions of CEO and chairman need to separate as duality mainly leaves one person with undisputable powers. The separation of offices of CEO and chairman mainly leads to counter checks which are very important for the smooth running of the company. This also applies that if one officeholder makes a rash decision he could be countered by the other. This also enables the $\mathrm{BoD}$ to exercise its influence and thus reduce the cause for asymmetry in information. Braun [31] points out that in such scenarios, the agency cost is reduced as shareholders are able to assess the information disclosed by the company and this reduces agency cost as they would feel that their management is looking after their interests. In light of agency theory, the conflict and costs related to the conflicts between shareholders and management can be reduced if the offices of CEO and chairman are separated from one another. This might also increase information disclosure and generally has positive impact on the overall performance of the company.

\subsection{Literature Review and Research Hypothesis}

Corporate social responsibility reporting is considered a vital part of overall corporate reporting but this might not be the case in developing countries. Abdul Rahman and Haneem Mohamed Ali [32] suggest that in the case of developing countries, most companies are family-owned and operated enterprises, thus they are always reluctant to disclose such information mainly because of lack of shareholder activism and weak regulation. The management of such companies always points to the additional cost of CSR discourse and mostly argues that such reporting reduces their potential wealth and thus they would deviate from the primary objective of shareholders' wealth maximization. Another issue in such a business environment relates to the lack of activism from other stakeholders who are directly or indirectly affected by the actions of companies, such as the general public, employees, local governments, etc. This phenomenon seems to change over time especially after the globalization and advent of information technology. Even in the emerging markets, CSR reporting is gaining momentum and governments are now actively passing regulations that bind companies to follow best practices and also disclose such activities in their reports. One of the prime examples, in this case, is China, which has made it compulsory for all listed companies to issue CSR reports along with their annual reports [33]. Researchers such as Veprauskaite and Adams [34] followed by [35] state that in any economy if a few companies start issuing such reports, the others tend to imitate or follow them as CSR reporting is believed to reduce asymmetric information and thus increases the confidence of shareholders and other stakeholders.

When it comes to the power structure of any commercial enterprise, the CEO is considered one of the most important players, as the $\mathrm{CEO}$ can influence the $\mathrm{BoD}$ in many ways, such as reporting and disclosure. This can be done by obstructing the BoD's power to monitor and report business 
activities, especially relating to CSR. The CEO is able to do this in cases when he/she is more powerful than the BoD and such power is granted by ownership, family-owned enterprise, or unlimited tenure time [36,37].Dalton and Kesner [38], followed by [29], also note that in such scenarios the CEO can easily influence the decision of the $\mathrm{BoD}$, thus reducing its effectiveness and powers. Zahra and Pearce [39] point out that such dominating influence and power mostly leads to prevailing of a single point of view rather than a comprehensive discussion and wider range of points of view, which can have a detrimental impact on the performance of the companies. Cannella Jr and Shen [40] state that if a CEO also chairs the BoD than the influence is even greater and since the chairman of the board approves the agenda of important meetings such as AGMs, he/she is able to control the issues which are needed to be discussed by board, depriving them of essential functions, such as effective mentoring [41]. In such a situation, the CEO can also influence the selection of board members and usually, the member is selected not on their competence but their loyalty to the CEO, which also can compromise their independence.

Although there could be many reasons for such behavior and power of CEOs, as discussed earlier, Haniffa and Cooke [7] point out two major factors for the existence of such power of CEOs. They argue that in the case of separation of offices of CEO and chairman, the power structure is balanced, and the board is able to perform its basic function of monitoring, thus increasing the efficiency of the company. At the same time, this argument might not be valid for all companies as many family-owned and operated organizations seem to perform and grow at a better pace than the companies where such structure is present. In such cases, even though the company is operating fairly, the power structure allows the CEO to ignore concerns of the other stakeholders, which in turn reduces their focus on activities that benefit local communities, reducing their CSR activities. Therefore, they might not be interested in such disclosures, citing the cost of disclosure as the main reason. Jensen and Meckling [26] argue that in such setups the CEO will always align the interests of shareholders and management as he/she also holds some portion of the equity and such action will also benefit him/her. On the contrary, [42] argues that in such cases, the managers become entrenched in self-interest and may ignore the wider organizational policies which have negative impact on the overall organization and can even reduce efficacy and innovation.

According to [Sial, Zheng [1], Ntim and Soobaroyen [43], effective corporate governance practices leads to companies to abide by corporate social regulations. These companies follow best practices that not only include shareholders but also tend to look after the interests of other stakeholders [44]. These actions enhance their reputation and increase public trust in these companies, which have a positive impact on their overall profitability and performance. This argument provides basics against the duality of CEO, as duality mostly results in ignoring of stakeholders as mentioned above.

Chau and Gray [45] support the adverse impact of managerial ownership on the CSR disclosure index. Morck, Shleifer [46] point to entrenchment as the main cause of the lack of CSR activities and disclosure in family-owned businesses; their point of view is fully supported by research by $[47,48]$. Hermalin and Weisbach [49] also confirm the existence of such issues and also note the negative impact of entrenchment on the performance of companies. The duration of a CEO's role is also considered a major factor that gives rise to agency problems. [50] point out that if a CEO retains their office for a long period or multiple durations, his/her influence on the board tends to increase, thus compromising its independence and decision-making abilities [51]. In the case of family-owned and operated companies, the CEO is not only a shareholder but also belongs to the owning family and thus mainly protects the interests of the family. This might leave out the minority shareholders and other stakeholders such as employees and the general public. Demsetz and Lehn [52] argue that in such cases the CEO tends to meet the expectations of family members as head of the family by considering their opinions and concerns about how the company should be run and this might overshadow the actual goal of wealth maximization. Muttakin, Khan [4], Gomez-Mejia, Nunez-Nickel [53] suggest that in such cases the accountability of the CEO is very low as he/she manages to keep the family members who also occupy power positions happy, and the CEO and board members are less motivated compared to those of 
non-family owned businesses, simply because they do not have to worry about shareholder activism. Therefore, most CEOs in those organizations further their self-interest at the cost of CSR activities and reporting. These overwhelming arguments have led to the basis of our hypothesis

Hypothesis 1 (H1). There is an adverse relationship between the power of the CEO and the disclosure level of CSR.

\section{Research Design}

\subsection{Sample and Data}

For the purpose of this study, we choose a sample of Chinese companies that are listed on the Shanghai Stock Exchange. The time span was 10 years starting from 2010 until 2019. Companies listed after 2019 were not considered. The data was obtained from the CSMAR database, related to their financial performance and corporate governance. Meanwhile, their CSR information was extracted from a variety of sources such as their CSR reports, director's statements, statements of their chairman, and related notes accompanying their audited financial statements.

\subsection{Model}

Following previous studies [14,54], regression analysis was conducted in order to examine the impact of CEO power on CSR disclosure level. Variance inflation factor (VIF) was used to test basic underlying assumptions of the regression model to be utilized, as per suggestions of Ali, Sial [54], who held that variables should have variance inflation factors in excess of 10 and also suggested that multicollinearity does not have any impact on the interpretation of the results obtained from a regression model.

The suggested regression equations are as follows:

$$
\begin{gathered}
\text { CSRD }_{i t}=\beta_{0}+\beta_{1} \text { CEOP }_{i t}+\beta_{2} \text { B.Size }_{i t}+\beta_{3} \text { F.Size }_{i t}+\beta_{4} \text { F.Age }_{i t}+\beta_{5} \text { Ind. } D_{i t}+\beta_{6} \text { ROA }_{i t}+ \\
\beta_{7} \text { Lev }_{i t}+\beta_{8} \text { YearDum }_{i t}+\beta_{9} \text { Industry Dum }_{\text {it }}+\epsilon_{\text {it }}
\end{gathered}
$$

\subsection{Measurement of Dependent Variable}

The dependent variable in this study was the disclosure of CSR denoted by term CSRD. This variable was assessed by a combination of 20 criteria based upon prior research on the topic and suggested by [55] further endorsed by [56]. These criteria were summarized into four major categories of (i) value-added information, (ii) environment, (iii) products and services, and (iv) employee and community. The involvements in activities related to community items were donation to charities, sponsorship of health and education-related activities. The major theme in regard to the environment included in this study was environmental disclosure by companies. The theme for employee-related information comprised of:(i) the relationship between employees and company, (ii) welfare, (iii) training and development of the human resource, (iv) employee education, (v) salaries, (vi) a portion of profits provided to employees, (vii) actions taken in regard to elimination of child labor, and (viii) occupational health and safety. Six items are taken under the theme of product and service: (i) awards received from customer associations, (ii) disclosure of information related to products, (iii) research and development of products, (iv) quality of the products along with their safety (v) the strength of the marketing network, and (vi) customer satisfaction. The value-added statement is taken as a measure of the information theme.

The company was awarded 1 rank for inclusion of the criterion listed above, otherwise, no rank awarded. The CSR disclosure was done by content analysis and in order to avoid "coder reliability issues", the following cautionary measures were taken: the CSR scores were calculated based upon the method used by [7] and later by [57], as they calculated the ratio of scores obtained by companies based upon five years of observation. 


\subsection{Measurement of Independent Variable}

The independent variable for this study was CEO power. When this study analyzed the existing literature for an assessment of CEO power, there was no universal measure. In addition, different dimensions are used by different authors to assess CEO power. [Jackling and Johl [36], Hermalin and Weisbach [49] use the shareholding of the CEO. The tenure of the CEO is used to assess the power by [58]. The monetary compensation and benefits received by the CEO are utilized by $[59,60]$. For our analysis, this study developed a separate index to assess the power of the CEO by combining several dimensions. For the development of this index, we followed [34]. The main items considered in this study were the duality, tenure, ownership, and family status of the CEO. Monetary compensation was ignored due to time and data constraints. We used dummy variables of 0 and 1 to calculate the scores. If the CEO also held the position of chairperson, then the score would be 1 otherwise zero.

\subsection{Measurement of Control Variables}

Control variables for the purpose of this study were board size (B.Size); size of the firm (F.Size);age of the firm (F.Age);independence of the board (Ind.D);return on assets i.e., net income divided by total assets (ROA)); and debt to equity ratio of company (leverage) (Lev).

Cheng and Courtenay [61] argues against larger boards, as he contends that these boards suffer from "free-rider" problems and states that in large boards the consensus of issues such as CSR might not be possible, so larger boards have a negative impact on CSR reporting. [62] argues in favor of large boards, as he contends that large board size is indicative of a company's attempt to connect with society and the general environment.

The size of the firm was calculated by taking the natural log of their assets. The larger companies have a greater impact on overall society due to the amount they can mobilize for such activities compared to smaller companies. Therefore, a positive relationship between firm size and CSR disclosure was expected.

Age of the firm was based upon the actual age of the company. Roberts [63] holds that companies tend to improve their disclosure with maturity as they are more concerned about their reputation, thus there is usually a positive relationship between the age of the company and CSR discourse.

The independence of the board of directors was assessed by the ratio of non-executive directors or independent directors present in the BoD. Haniffa and Cooke [7] state that the presence of non-executive directors or independent directors ensures that the minority interest is also protected, and their presence also improve disclosures and reporting such as CSR. Zahra and Stanton [64] also state that the presence of these directors usually improves the reporting and disclosure standards. So, the presence of non-executive directors or independent directors was expected to have a positive impact on CSR disclosures.

The profitability of the company was measured by calculating the return on its assets. It is generally held that profitable companies tend to be more concerned about CSR activities and disclosures.

We analyzed the impact of leverage (Lev) on disclosure.Schipper [65] contends that highly leveraged companies disclose more information to their creditors to assure them that they are following their covenants.

\section{Results}

\subsection{Descriptive Statistics}

Table 1 explains the descriptive statistics of variables related to corporate social responsibility disclosure and corporate governance variables. 
Table 1. Descriptive Statistics.

\begin{tabular}{cccc}
\hline Variable & Obs & Mean & Std. Dev \\
\hline CSRD & 6252 & 0.3641 & 0.1173 \\
CEOP & 6252 & 0.8197 & 0.3139 \\
B.Size & 6252 & 9.5454 & 2.2093 \\
F.Size & 6252 & 23.0765 & 1.6491 \\
F.Age & 6252 & 12.5838 & 3.4348 \\
Ind.D & 6252 & 0.3699 & 0.0762 \\
ROA & 6252 & 0.0528 & 0.0751 \\
Lev & 6252 & 0.5098 & 0.1168 \\
\hline
\end{tabular}

The sample consists of Chinese companies from 2010 to 2019. The dependent variable is CSRD (corporate social responsibility disclosure), measured by using a dichotomous procedure, 1 if an item disclosed and 0 if it not. This variable was assessed by a combination of 20 criteria based on prior research. These criteria were summarized into four major categories of value-added information, environment, products and services, and employee and community).The independent variable for this study is CEOP(CEO power), using dummy variables of 0 and 1 to calculate the scores. If the CEO also held the position of chairperson, then the score would be 1 , otherwise 0 . B.Size-board size, total number of directors in the board; F.Size-Firm size, natural log of their assets; F.Age-Firm age, the actual age of company; Ind.D-Independent director, ratio of non-executive directors present in the board of directors; ROA—return on assets, net income divided by total assets; Lev—Leverage measured by taking debt to equity ratio of company.

The mean value of disclosures related to CSR is 0.3641 . The mean value of the power of the CEO (denoted by CEOP) index is 0.8197 . In our sample, the firms had ROA around $5 \%$. The mean value of firm size (F.Size) was 23.07 and the average firm age (F.Age) in our sample was about 12 years.

\subsection{Correlation Matrix}

Table 2 presents the correlation matrix. As per our findings, the relationship between the power of CEO and corporate social responsibility denoted by CSRD negatively correlated at a $5 \%$ level of confidence.

Table 2. Correlation Matrix.

\begin{tabular}{|c|c|c|c|c|c|c|c|c|c|c|}
\hline & 1 & 2 & 3 & 4 & 5 & 6 & 7 & 8 & VIF & 1/VIF \\
\hline 1-CSRD & 1.0000 & & & & & & & & & \\
\hline 2-CEOP & $-0.0493^{* * *}$ & 1.0000 & & & & & & & 1.05 & 0.954960 \\
\hline 3-B.Size & $0.1108^{* * *}$ & $-0.1416 * * *$ & 1.0000 & & & & & & 1.40 & 0.716485 \\
\hline 4-F.Size & $0.2217^{* * *}$ & $-0.1328^{* * *}$ & $0.4456^{* * *}$ & 1.0000 & & & & & 1.89 & 0.529608 \\
\hline 5-F.Age & $0.0952 * * *$ & $-0.1278^{* * *}$ & $0.0409 * *$ & $0.4894^{* * *}$ & 1.0000 & & & & 1.09 & 0.914932 \\
\hline 6-Ind.D & $0.0306^{* * *}$ & $0.0867^{* * *}$ & $-0.2468^{* * *}$ & $0.0541^{* *}$ & $0.1117^{* * *}$ & 1.0000 & & & 1.12 & 0.895010 \\
\hline 7-ROA & $0.0657^{* * *}$ & $0.0814^{* * *}$ & $-0.0931^{* * *}$ & $-0.1584^{* * *}$ & -0.1363 & $0.1409^{* *}$ & 1.0000 & & 1.17 & 0.856601 \\
\hline 8-Lev & $-0.1314^{* * *}$ & $-0.1254^{* * *}$ & $0.2577^{* * *}$ & $0.1959^{* * *}$ & $0.2620^{* * *}$ & $0.0204 * *$ & $-0.3653^{* * *}$ & 1.0000 & 1.80 & 0.554060 \\
\hline
\end{tabular}

The sample consists of Chinese companies from 2010 to 2019. The dependent variable is CSRD (corporate social responsibility disclosure), measured by using a dichotomous procedure, 1 if an item disclosed and 0 if it not. This variable was assessed by a combination of 20 criteria based on prior research. These criteriawere summarized into four major categories of value-added information, environment, products and services, and employee and community).The independent variable for this study is CEOP(CEO power), using dummy variables of 0 and 1 to calculate the scores. If the CEO also held the position of chairperson, then the score would be 1, otherwise 0 . B.Size - board size, total number of directors in the board; F.Size-Firm size, natural log of their assets; F.Age-Firm age, the actual age of company; Ind.D-Independent director, ratio of non-executive directors present in the board of directors;ROA - return on assets, net income divided by total assets; Lev-Leverage measured by taking debt to equity ratio of company. ${ }^{* * *},{ }^{* *}$ represent $p<0.01, p<0.05$, respectively.

In the case of control variables, only one variable, leverage (Lev), had negative correlations with disclosure related to CSR (CSRD). Meanwhile, the other control variables ofthe size of the board (B.Size), size of the firm (F.Size), the lag value of the age of the company (F.Age), independence of the board (Ind.B), and return on assets (ROA) had positive impact on the disclosure related to CSR. The maximum correlation between firm age and firm size is (0.4894). Therefore, no multicollinearity problem exists. Table 2 also suggests that there was no multicollinearity problem in the data that can 
affect results. Further, the variance inflationary factor was under the limit of 3 , and the value was less than 0.60 of correlation between all variables under consideration, which is under the maximum level.

\title{
4.3. Regression Analysis and Discussion of Results
}

Table 3 represents the results of the regression on CEO power and the level of CSR disclosures.

Table 3. CEO Power and CSR Disclosure

\begin{tabular}{|c|c|c|c|c|}
\hline \multirow{2}{*}{ Variables } & \multicolumn{2}{|c|}{ Model 1 (CSRD), POLS } & \multicolumn{2}{|c|}{ Model 2 (CSRD),2SLS } \\
\hline & Coef & $p$-Value & Coef & $p$-Value \\
\hline CEOP & -0.0155 & 0.006 & -0.0164 & 0.005 \\
\hline B.Size & 0.0131 & 0.060 & 0.0129 & 0.091 \\
\hline F.Size & 0.0755 & 0.000 & 0.0753 & 0.000 \\
\hline F.Age & 0.0111 & 0.008 & 0.0109 & 0.010 \\
\hline Ind.D & 0.0269 & 0.052 & 0.0437 & 0.049 \\
\hline $\mathrm{ROA}$ & 0.0793 & 0.085 & 0.0085 & 0.084 \\
\hline Lev & -0.0110 & 0.043 & -0.0110 & 0.043 \\
\hline Industry Dummies & \multicolumn{2}{|c|}{ YES } & \multicolumn{2}{|c|}{ YES } \\
\hline Year Dummies & \multicolumn{2}{|c|}{ YES } & \multicolumn{2}{|c|}{ YES } \\
\hline Adjusted $\mathrm{R}^{2} / \mathrm{R}^{2}$ & \multicolumn{2}{|c|}{$12.93 \%$} & \multicolumn{2}{|c|}{13.52} \\
\hline F-Statistic/ Wald $\mathrm{Ch}^{2}$ & \multicolumn{2}{|c|}{22.07} & \multicolumn{2}{|c|}{659.62} \\
\hline Prob (F-Statistic) & \multicolumn{2}{|c|}{0.000} & \multicolumn{2}{|c|}{0.000} \\
\hline
\end{tabular}

\begin{abstract}
The sample consists of Chinese companies from 2010 to 2019. The dependent variable is CSRD (corporate social responsibility disclosure), measured by using a dichotomous procedure, 1 if an item disclosed and 0 if it not. This variable was assessed by a combination of 20 criteria based on prior research. These criteriawere summarized into four major categories of value-added information, environment, products and services, and employee and community).The independent variable for this study is CEOP(CEO power), using dummy variables of 0 and 1 to calculate the scores. If the CEO also held the position of chairperson, then the score would be 1 , otherwise 0 . B.Size - board size, total number of directors in the board; F.Size—Firm size, natural log of their assets; F.Age-Firm age, the actual age of company; Ind.D-Independent director, ratio of non-executive directors present in the board of directors;ROA - return on assets, net income divided by total assets; Lev—Leverage measured by taking debt to equity ratio of company.
\end{abstract}

Our investigation was on the impact of the power of CEO (CEOP) on the level of disclosures related to CSR. The correlation was significant and negative at a $99 \%$ confidence level. This was in line with our hypothesis, implying that the more power held by the CEO, the lower the level of CSR disclosure. Our findings further validated earlier findings of [Fabrizi, Mallin [66], Ahmad, Rashid [67] who hold that in environments where the legal system is weak and companies are mostly owned and operated by families, the CEOs are entrenched in self- and family-interest and are unlikely to pay much attention to CSR activities and disclosure. Thus, powerful CEOs tend to be less interested in using issues such as CSR to gain legitimacy. In firms where CEOs have a greater level of power, there is a general tendency not only to ignore corporate social responsibility activities but also to save on the costs related to reporting CSR.

The powerful CEOs mostly are uninterested in performing the CSR activities as they do not have any interest in CSR as they do not have to legitimize themselves, in other words, they tend to legitimize their powers by saving cost on such disclosure.

Regarding the control variables firm size (F.Size), firm age (F.Age), and return on assets (ROA), in both models they were significantly positively related to CSR disclosure. Regarding leverage, there was a negative relationship between leverage and CSR disclosure; this showed that our sample of Chinese companies with higher levels of leverage tended to increase their disclosure in order to satisfy their creditors and other stakeholders. These findings were in line with those of [68]. At the same time, having an independent board of directors had a positive impact on the CSR disclosure; these results are not surprising as similar findings were held by earlier studies of $[7,69]$. In other words, our findings in the case of Chinese non-financial firms were inline with the literature. The results of our analysis in relation to the control variables were consistent with previous studies $[4,7]$. 
To address the possible problem of causality, we ran a two-stage least squares (TSLS) regression in model 2. As in our previous model, we showed that CEO power was significant and negative at the level of $99 \%$. Regarding the control variables in model 2, the results were similar to model 1.

\subsection{Robustness Test}

The current study performed an additional test in order to confirm the main findings. The robustness test was carried out to further validate our earlier findings. The results of our tests are presented in Table 4. This study checked the effect of CEO power on different categories of CSR disclosure. In Table 4, including from model 1 to model 4, this study performed the effect of CEO power on environmental disclosure by companies (En.D), the relationship between employees and their companies (Em.D), value addition-related disclosures (Va.D), and product-related disclosures (Pr.D) respectively.

Table 4. Robustness Test - OLS Regression

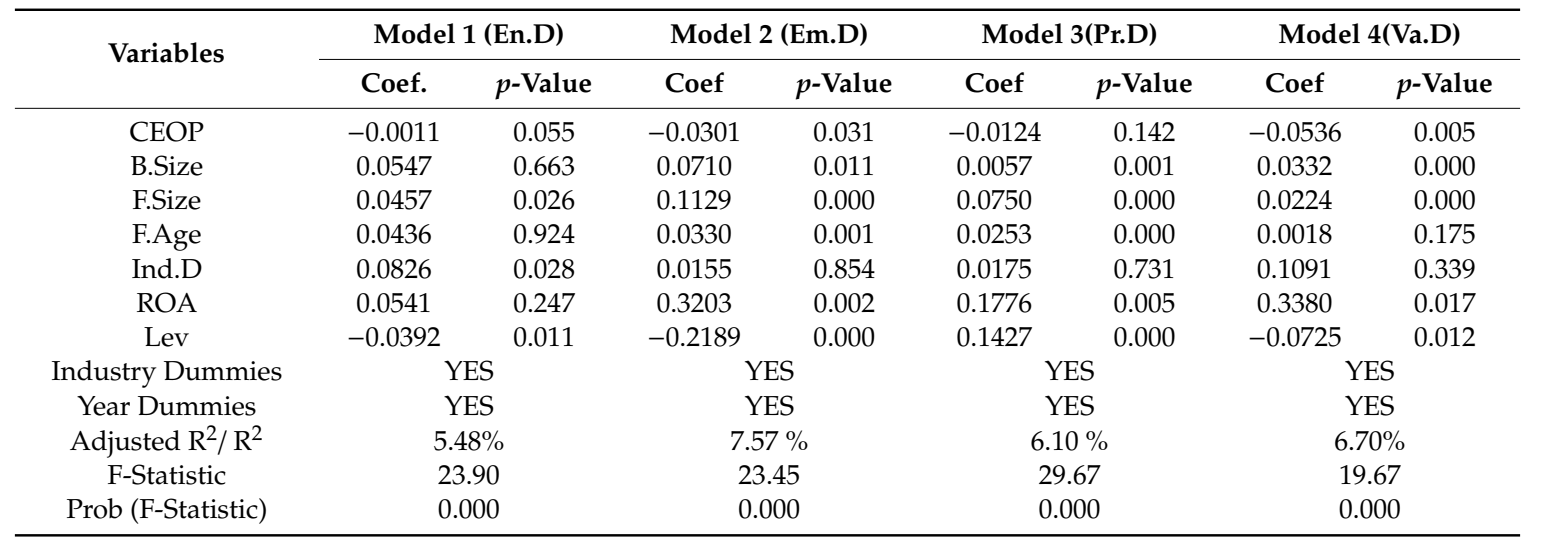

The sample consists of Chinese companies from 2010 to 2019. The dependent variables are En.D-environmental disclosure by companies, Em.D—the relationship between employees and their companies, Pr.D—product-related disclosures, Va.D - value addition-related disclosures. The independent variable for this study is CEOP(CEO power), using dummy variables of 0 and 1 to calculate the scores. If the $\mathrm{CEO}$ also held the position of chairperson, then the score would be 1, otherwise 0. B.Size-board size, total number of directors in the board; F.Size-Firm size, natural log of their assets; F.Age-Firm age, the actual age of company; Ind.D—Independent director, ratio of non-executive directors present in the board of directors; ROA-return on assets, net income divided by total assets; Lev-Leverage measured by taking debt to equity ratio of company.

After the application of regression models for En.D, Em.D, Pr.D, and Va.D, the coefficient estimates of four sub-categories of CSR disclosures were consistent with our main findings in Table 3, implying that the power of the CEO had an adverse relationship with subcategories of CSR disclosures. The coefficients of the control variable were similar to our earlier findings.

All of the necessary tests for checking robustness were applied. This study found that in the case of Chinese non-financial companies in the presence of a powerful CEO, even the independent director would refrain from investing in CSR activities and the level of reporting was seen as a waste of resources and thus reduced to a minimum. The CEO power could also be measured using the scale defined in the study. This was tested by applying a dummy variable of 1 if the power of the CEO was above mean value and zero if it was below the mean value. One of the main findings of this study related to CEO power, which led us to believe that the more powerful the CEO, the less CSR-related disclosure in the Chinese business environment. Even when OLS regression was applied to each of the original equations, the results remained fairly unchanged, thus further validating our findings. The last step was to apply fixed effects regressions in Table 5, which gave similar results to OLS regression, further confirming the robustness of our results and validating our key findings. 
Table 5. Robustness Test. Fixed effect Regression

\begin{tabular}{|c|c|c|c|c|c|c|c|c|}
\hline \multirow{2}{*}{ Variables } & \multicolumn{2}{|c|}{ Model 1 (En.D) } & \multicolumn{2}{|c|}{ Model 2 (Em.D) } & \multicolumn{2}{|c|}{ Model 1 (Pr.D) } & \multicolumn{2}{|c|}{ Model 1 (Va.D) } \\
\hline & Coef. & $p$-Value & Coef & $p$-Value & Coef & $p$-Value & Coef & $p$-Value \\
\hline CEOP & -0.0032 & 0.063 & -0.0312 & 0.0517 & -0.0280 & 0.065 & -0.0682 & 0.070 \\
\hline F.Size & 0.0641 & 0.065 & 0.0190 & 0.158 & 0.0116 & 0.062 & 0.2100 & 0.000 \\
\hline F.Age & 0.0575 & 0.456 & 0.0290 & 0.330 & 0.0263 & 0.065 & 0.0767 & 0.055 \\
\hline Ind.D & 0.0136 & 0.074 & 0.1024 & 0.206 & 0.0691 & 0.086 & 0.4233 & 0.069 \\
\hline Lev & -0.0159 & 0.043 & -0.0461 & 0.306 & -0.0647 & 0.015 & -0.3497 & 0.056 \\
\hline Industry Dummies & \multicolumn{2}{|c|}{ YES } & \multicolumn{2}{|c|}{ YES } & \multicolumn{2}{|c|}{ YES } & \multicolumn{2}{|c|}{ YES } \\
\hline Year Dummies & \multicolumn{2}{|c|}{ YES } & \multicolumn{2}{|c|}{ YES } & \multicolumn{2}{|c|}{ YES } & \multicolumn{2}{|c|}{ YES } \\
\hline $\mathrm{R}^{2}$ & \multicolumn{2}{|c|}{$5.68 \%$} & \multicolumn{2}{|c|}{$11.23 \%$} & \multicolumn{2}{|c|}{7.13} & \multicolumn{2}{|c|}{$6.65 \%$} \\
\hline Wald $\mathrm{Ch}^{2}$ & \multicolumn{2}{|c|}{151.42} & \multicolumn{2}{|c|}{18.18} & \multicolumn{2}{|c|}{16.15} & \multicolumn{2}{|c|}{17.69} \\
\hline
\end{tabular}

The sample consists of Chinese companies from 2010 to 2019. The dependent variables are En.D—environmental disclosure by companies, Em.D—the relationship between employees and their companies, Pr.D—product-related disclosures, Va.D—value addition-related disclosures. The independent variable for this study is CEOP(CEO power), using dummy variables of 0 and 1 to calculate the scores. If the $C E O$ also held the position of chairperson, then the score would be 1, otherwise 0. B.Size-board size, total number of directors in the board; F.Size-Firm size, natural log of their assets; F.Age-Firm age, the actual age of company; Ind.D—Independent director, ratio of non-executive directors present in the board of directors; ROA-return on assets, net income divided by total assets; Lev—Leverage measured by taking debt to equity ratio of company.

\section{Conclusions and Future Research}

The main aim of the study was to determine the strength of CEOs' influence on CSR in the Chinese listed companies. The results of the present study indicated a negative relationship between CEO power and CSR disclosure, implying that the more power a CEO exerts the lower the quality of CSR disclosure. This could also be seen as powerful CEOs can prohibit improvements in disclosing structure as CSR reporting is mainly seen as the improvement in reporting structure in the case of Chinese companies. These findings are important to policymakers and regulators. The main implication related to the power of CEO, if the CEO becomes powerful, he/she could be more likely to choose directors based upon loyalty rather than competence and thus the directors are more likely to be less independent. This, in turn, could hinder their main function of monitoring and reporting. The findings of our study also could be helpful to the public, government, and economic sectors to build CSR programs. The main contribution of this study relates to the bridging of the gap between one school of thought on a current topic, namely agency theory.

One of the main limitations of this study was that this study did not consider the quality of CSR discourse, because the majority of companies included in the research sample did not provide the CSR disclosure in measurable form. In addition, this disclosure was voluntary and thus limited. This could be addressed by future research. The second is related to the data set, which comprised of a single nation. In other words, the results of this study cannot be generalized and applicable all over the region or world. The final limitation related to the abilities of directors, which could be determined by considering proxies including age [70], the practical experience of the director in different capacities [71], and experience working in senior company positions [72].They could not be determined due to the lack of disclosure in this regard, so future studies can utilize these factors by obtaining data on characteristics of directors to further validate our findings.

Author Contributions: All the authors contributed to conceptualization, formal analysis, investigation, methodology, writing-original draft, and writing-review \& editing. All authors have read and agreed to the published version of the manuscript.

Funding: This research received no external funding.

Conflicts of Interest: The authors declare no conflict of interest. 


\section{References}

1. Sial, M.S.; Zheng, C.; Khuong, N.V.; Khan, T.; Usman, M. Does Firm Performance Influence Corporate Social Responsibility Reporting of Chinese Listed Companies? Sustainability 2018, 10, 2217. [CrossRef]

2. Ho, S.S.; Wong, K.S. A study of the relationship between corporate governance structures and the extent of voluntary disclosure. J. Int. Account. Audit. Tax. 2001, 10, 139-156. [CrossRef]

3. Gul, F.A.; Leung, S. Board leadership, outside directors' expertise and voluntary corporate disclosures. J. Account. Public Policy 2004, 23, 351-379. [CrossRef]

4. Muttakin, M.B.; Khan, A.; Mihret, D.G. The effect of board capital and CEO power on corporate social responsibility disclosures. J. Bus. Ethics 2018, 150, 41-56. [CrossRef]

5. Klein, A. Audit committee, board of director characteristics, and earnings management. J. Account. Econ. 2002, 33, 375-400. [CrossRef]

6. Davidson, R.; Goodwin-Stewart, J.; Kent, P. Internal governance structures and earnings management. Account. Financ. 2005, 45, 241-267. [CrossRef]

7. Haniffa, R.M.; Cooke, T.E. The impact of culture and governance on corporate social reporting. J. Account. Public Policy 2005, 24, 391-430. [CrossRef]

8. Jo, H.; Harjoto, M.A. Corporate governance and firm value: The impact of corporate social responsibility. J. Bus. Ethics 2011, 103, 351-383. [CrossRef]

9. Parker, J. Integrating CSR with hospitality management programmes in higher education. Int. J. Green Econ. 2011, 5, 396-404. [CrossRef]

10. Post, W. Top Secret America. Series. Available online: http://projects.washingtonpost.com/top-secretamerica/ articles/editors-note (accessed on 12 March 2020).

11. Al Farooque, O.; Ahulu, H. Determinants of social and economic reportings: Evidence from Australia, the UK and South African multinational enterprises. Int. J. Account. Inf. Manag. 2017, 25, 177-200. [CrossRef]

12. Sobhan, E.F.; Werner, W. A Comparative Analysis of Corporate Governance in South Asia: Charting a Roadmap for Bangladesh; Bangladesh Enterprise Institute: Dhaka, Bangladesh, 2003.

13. Brennan, N.M.; Solomon, J.; Uddin, S.; Choudhury, J. Rationality, traditionalism and the state of corporate governance mechanisms. Account. Audit. Account. J. 2008, 21, 1026-1051.

14. Sial, M.S.; Chunmei, Z.; Khuong, N.V. Do female and independent directors explain the two-way relationship between corporate social responsibility and earnings management of Chinese listed firms? Int. J. Account. Inform. Manag. 2019, 27, 442-460. [CrossRef]

15. Sial, M.S.; Xuan, V.V.; Lara, A.-H.; Thao, N.T. Impact of female directors on the board and foreign institutional investors on earning manipulation of Chinese listed companies. Asia-Pac. J. Bus. Adm. 2019. [CrossRef]

16. Subramaniam, M.D.; Kim, I.H. Clays as dietary supplements for swine: A review. J. Anim. Sci. Biotechnol. 2015, 6, 38. [CrossRef]

17. Reeb, D.M.; Zhao, W. Director capital and corporate disclosure quality. J. Account. Public Policy 2013, 32, 191-212. [CrossRef]

18. Vo, X.V. Does institutional ownership increase stock return volatility? Evidence from Vietnam. Int. Rev. Financ. Anal. 2016, 45, 54-61. [CrossRef]

19. Vo, X.V. Foreign ownership and stock market liquidity-evidence from Vietnam. Afro Asian J. Financ. Account. 2016, 6, 1-11. [CrossRef]

20. Vo, X.V. How does the stock market value bank diversification? Evidence from Vietnam. Financ. Res. Lett. 2017, 22, 101-104. [CrossRef]

21. Vo, X.V. Do foreign investors improve stock price informativeness in emerging equity markets? Evidence from Vietnam. Res. Int. Bus. Financ. 2017, 42, 986-991. [CrossRef]

22. Vo, X.V. Trading of foreign investors and stock returns in an emerging market-Evidence from Vietnam. Int. Rev. Financ. Anal. 2017, 52, 88-93. [CrossRef]

23. Vo, X.V. The role of bank funding diversity: Evidence from Vietnam. Int. Rev. Financ. 2018. [CrossRef]

24. Vo, X.V. Bank lending behavior in emerging markets. Financ. Res. Lett. 2018, 27, 129-134. [CrossRef]

25. Vo, X.V. Foreign ownership and corporate cash holdings in emerging markets. Int. Rev. Financ. 2018, 18, 297-303. [CrossRef]

26. Jensen, M.C.; Meckling, W.H. Theory of the firm: Managerial behavior, agency costs and ownership structure. J. Financ. Econ. 1976, 3, 305-360. [CrossRef] 
27. Davis, K. The case for and against business assumption of social responsibilities. Acad. Manag. J. 1973, 16, 312-322.

28. Fama, E.F. Agency Problems and the Theory of the Firm. J. Political Econ. 1980, 88, 288-307. [CrossRef]

29. Boyd, B.K. CEO duality and firm performance: A contingency model. Strateg. Manag. J. 1995, 16, $301-312$. [CrossRef]

30. Nada, N.; Kholief, M.; Tawfik, S.; Metwally, N. Mobile knowledge tool-kit to create a paradigm shift in higher education. Electron. J. Knowl. Manag. 2009, 7, 255-260.

31. Braun, P. Going green: Women entrepreneurs and the environment. Int. J. Gend. Entrep. 2010, 2, $245-259$. [CrossRef]

32. Abdul Rahman, R.; Haneem Mohamed Ali, F. Board, audit committee, culture and earnings management: Malaysian evidence. Manag. Audit. J. 2006, 21, 783-804. [CrossRef]

33. Ahmed Haji, A. Corporate social responsibility disclosures over time: Evidence from Malaysia. Manag. Audit. J. 2013, 28, 647-676. [CrossRef]

34. Veprauskaite, E.; Adams, M. Do powerful chief executives influence the financial performance of UK firms? Br. Account. Rev. 2013, 45, 229-241. [CrossRef]

35. Amran, A.; Siti-Nabiha, A. Corporate social reporting in Malaysia: A case of mimicking the West or succumbing to local pressure. Soc. Responsib. J. 2009, 5, 358-375. [CrossRef]

36. Jackling, B.; Johl, S. Board structure and firm performance: Evidence from India's top companies. Corp. Gov. Int. Rev. 2009, 17, 492-509. [CrossRef]

37. Javeed, S.A.; Lefen, L. An analysis of corporate social responsibility and firm performance with moderating effects of CEO power and ownership structure: A case study of the manufacturing sector of Pakistan. Sustainability 2019, 11, 248. [CrossRef]

38. Dalton, D.R.; Kesner, I.F. Composition and CEO duality in boards of directors: An international perspective. J. Int. Bus. Stud. 1987, 18, 33-42. [CrossRef]

39. Zahra, S.A.; Pearce, J.A. Boards of directors and corporate financial performance: A review and integrative model. J. Manag. 1989, 15, 291-334. [CrossRef]

40. Cannella, A.A., Jr.; Shen, W. So close and yet so far: Promotion versus exit for CEO heirs apparent. Acad. Manag. J. 2001, 44, 252-270.

41. Ricketts, T.; Imhoff, M. Biodiversity, urban areas, and agriculture: Locating priority ecoregions for conservation. Conserv. Ecol. 2003, 8. [CrossRef]

42. Demsetz, H. The structure of ownership and the theory of the firm. J. Law Econ. 1983, 26, 375-390. [CrossRef]

43. Ntim, C.G.; Soobaroyen, T. Black economic empowerment disclosures by South African listed corporations: The influence of ownership and board characteristics. J. Bus. Ethics 2013, 116, 121-138. [CrossRef]

44. Devinney, T.M.; Schwalbach, J.; Williams, C.A. Corporate social responsibility and corporate governance: Comparative perspectives. Corp. Gov. Int. Rev. 2013, 21, 413-419. [CrossRef]

45. Chau, G.; Gray, S.J. Family ownership, board independence and voluntary disclosure: Evidence from Hong Kong. J. Int. Account. Audit. Tax. 2010, 19, 93-109. [CrossRef]

46. Morck, R.; Shleifer, A.; Vishny, R.W. Management ownership and market valuation: An empirical analysis. J. Financ. Econ. 1988, 20, 293-315. [CrossRef]

47. Berger, P.G.; Ofek, E.; Yermack, D.L. Managerial entrenchment and capital structure decisions. J. Financ. 1997, 52, 1411-1438. [CrossRef]

48. Rosener, J. America's Competitive Secret: Utilizing Women as a Power Strategy; Oxford University Press: New York, NY, USA, 1995.

49. Hermalin, B.E.; Weisbach, M.S. Endogenously chosen boards of directors and their monitoring of the CEO. Am. Econ. Rev. 1998, 25, 96-118.

50. Chidambaran, N.K.; Prabhala, N.R. Executive stock option repricing, internal governance mechanisms, and management turnover. J. Econ. 2003, 69, 153-189. [CrossRef]

51. Ryan, H.E., Jr.; Wiggins, R.A., III. Who is in whose pocket? Director compensation, board independence, and barriers to effective monitoring. J. Financ. Econ. 2004, 73, 497-524. [CrossRef]

52. Demsetz, H.; Lehn, K. The structure of corporate ownership: Causes and consequences. J. Political Econ. 1985, 93, 1155-1177. [CrossRef]

53. Gomez-Mejia, L.R.; Nunez-Nickel, M.; Gutierrez, I. The role of family ties in agency contracts. Acad. Manag. J. 2001, 44, 81-95. 
54. Ali, R.; Sial, M.S.; Brugni, T.V.; Hwang, J.; Khuong, N.V.; Khanh, T.H.T. Does CSR Moderate the Relationship between Corporate Governance and Chinese Firm's Financial Performance? Evidence from the Shanghai Stock Exchange (SSE) Firms. Sustainability 2020, 12, 149. [CrossRef]

55. Rashid, A.; De Zoysa, A.; Lodh, S.; Rudkin, K. Board composition and firm performance: Evidence from Bangladesh. Australas. Account. Bus. Financ. J. 2010, 4, 76-95.

56. Muttakin, M.B.; Khan, A. Determinants of corporate social disclosure: Empirical evidence from Bangladesh. Adv. Account. 2014, 30, 168-175. [CrossRef]

57. Hafsi, T.; Turgut, G. Boardroom diversity and its effect on social performance: Conceptualization and empirical evidence. J. Bus. Ethics 2013, 112, 463-479. [CrossRef]

58. Brookman, J.; Thistle, P.D. CEO tenure, the risk of termination and firm value. J. Corp. Financ. 2009, 15, 331-344. [CrossRef]

59. Jiraporn, P.; Miller, G.A.; Yoon, S.S.; Kim, Y.S. Is earnings management opportunistic or beneficial? An agency theory perspective. Int. Rev. Financ. Anal. 2008, 17, 622-634. [CrossRef]

60. Florackis, C.; Kostakis, A.; Ozkan, A. Managerial ownership and performance. J. Bus. Res. 2009, 62, 1350-1357. [CrossRef]

61. Cheng, E.C.; Courtenay, S.M. Board composition, regulatory regime and voluntary disclosure. Int. J. Account. 2006, 41, 262-289.

62. Pfeffer, J. A resource dependence perspective on intercorporate relations. Intercorporate Relations: The Structural. Anal. Bus. 1987, 1, 25-55.

63. Roberts, G.E. Linkages between performance appraisal system effectiveness and rater and ratee acceptance. Rev. Public Pers. Adm. 1992, 12, 19-41. [CrossRef]

64. Zahra, S.A.; Stanton, W.W. The implications of board of directors composition for corporate strategy and performance. Int. J. Manag. 1988, 5, 229-236.

65. Schipper, K. Discussion of voluntary corporate disclosure: The case of interim reporting. J. Account. Res. 1981, 19, 85-88. [CrossRef]

66. Fabrizi, M.; Mallin, C.; Michelon, G. The role of CEO's personal incentives in driving corporate social responsibility. J. Bus. Ethics 2014, 124, 311-326. [CrossRef]

67. Ahmad, N.B.J.; Rashid, A.; Gow, J. CEO duality and corporate social responsibility reporting: Evidence from Malaysia. Corp. Ownersh. Control 2017, 14, 69-81. [CrossRef]

68. Purushothaman, M.; Tower, G.; Hancock, P.; Taplin, R. Determinants of corporate social reporting practices of listed Singapore companies. Pac. Account. Rev. 2000, 12, 101.

69. Roberts, R.W. Determinants of corporate social responsibility disclosure: An application of stakeholder theory. Account. Organ. Soc. 1992, 17, 595-612. [CrossRef]

70. Kim, C.H.; Amaeshi, K.; Harris, S.; Suh, C.-J. CSR and the national institutional context: The case of South Korea. J. Bus. Res. 2013, 66, 2581-2591. [CrossRef]

71. Singh, V.; Terjesen, S.; Vinnicombe, S. Newly appointed directors in the boardroom: How do women and men differ? Eur. Manag. J. 2008, 26, 48-58. [CrossRef]

72. Johnson, R.A.; Greening, D.W. The effects of corporate governance and institutional ownership types on corporate social performance. Acad. Manag. J. 1999, 42, 564-576.

(C) 2020 by the authors. Licensee MDPI, Basel, Switzerland. This article is an open access article distributed under the terms and conditions of the Creative Commons Attribution (CC BY) license (http://creativecommons.org/licenses/by/4.0/). 